\title{
Estimation of genetic parameters for individual udder quarter milk content traits in Brown Swiss cattle
}

\author{
M. Kramer, ${ }^{\star 1}$ M. Erbe,${ }^{*}$ B. Bapst, $†$ A. Bieber, $\ddagger$ and H. Simianer ${ }^{\star}$ \\ ${ }^{*}$ Department of Animal Science, Animal Breeding and Genetics Group, Georg-August-Universität Göttingen, Albrecht-Thaer-Weg 3 , \\ 37075 Göttingen, Germany \\ †Qualitas AG, Chamerstraße 56, 6300 Zug, Switzerland \\ $\ddagger$ FiBL-Research Institute of Organic Agriculture, Ackerstrasse, 5070 Frick, Switzerland
}

\begin{abstract}
The aim of this study was to estimate genetic parameters and accuracies of breeding values for milk content traits of individual udder quarters in Brown Swiss cattle. Data of 1,799 phenotyped cows from 40 Swiss dairy herds were analyzed, taking the complete pedigree into account. Fat, protein, lactose, and urea contents, somatic cell score (SCS), and information about hyperkeratosis were available for each udder quarter. The milk of rear udder quarters was found to have significantly higher lactose content and significantly lower fat content than milk of the front udder quarters. The same trend found for fat content was observed for protein content, whereas no differences between the udder quarters were observed for urea content, SCS, or hyperkeratosis. Heritabilities for each udder quarter were in the following ranges: fat content $0.09 \pm 0.06$ to $0.14 \pm$ 0.06 , protein content $0.20 \pm 0.09$ to $0.33 \pm 0.07$, lactose content $0.04 \pm 0.03$ to $0.16 \pm 0.07$, urea content 0.13 \pm 0.07 to $0.22 \pm 0.08$, SCS $0.18 \pm 0.06$ to $0.32 \pm 0.07$, and hyperkeratosis $0.12 \pm 0.04$ to $0.26 \pm 0.05$. In our study, hyperkeratosis, protein content, and SCS showed higher heritabilities in the front udder quarters, fat content had higher heritabilities in the rear udder quarters, and no systematic pattern in heritability was observed for lactose content or urea content. Additive genetic correlations between all udder quarters were $>0.90$ for protein and urea contents, whereas they were remarkably low $(<0.60)$ for SCS. For fat and lactose contents, the genetic correlations between the 2 front or between the 2 rear quarters, respectively, were notably higher than correlations between 1 front and 1 rear quarter, suggesting that the front and the rear udders could be considered as partly genetically different organs. The variability within the udder as such was found to be of low heritability $(<0.10)$ in general, but repeatability was moderate to high for some traits (lactose content:
\end{abstract}

Received October 5, 2012.

Accepted June 7, 2013.

${ }^{1}$ Corresponding author: mkramer@gwdg.de
$0.33 \pm 0.05$, protein content: $0.53 \pm 0.05)$. Some of these findings can be explained by differences in the physiological background of the traits.

Key words: genetic parameter, accuracy of breeding value, individual udder quarter milk content, withinudder variability

\section{INTRODUCTION}

Studies that analyze milk composition traits on the udder quarter level are rare, although measurements of the milk content on an udder quarter level are available from automatic milking systems. Forsbäck et al. (2010) stated that there is a need to understand variation in milk contents on the udder quarter level; for example, in order to enhance udder health. If a cow is suffering from mastitis, usually only one udder quarter is affected. Lactose content decreases during early mastitis. As mastitis proceeds, the SCS increases. Because of dilution, this effect might not be detected on a total milk composite level if only one udder quarter is affected. Although little is known to date about the genetic basis of the diversity of milk composition between udder quarters, this trait complex may provide some insight into the metabolic stability of a cow. Earlier studies (e.g., Berglund et al., 2007) showed that one individual udder quarter with altered SCS might be masked in the cow's composite milk. Hence, individual quarter measurements of milk composition and quality traits could help to detect mastitis earlier.

Another trait recorded for each individual udder quarter separately is hyperkeratosis. Neijenhuis et al. (2001) noted that hyperkeratosis was strongly influenced genetically and breeders could use lesion score as an additional indicator trait to improve udder health. Seykora and McDaniel (1985) found that front teats tend to have more severe hyperkeratosis than rear teats.

One aim of our study was to report means and estimates of (co-) variance components and genetic parameters (heritabilities, repeatabilities, genetic correlations) for measurements of fat, protein, lactose, and 
urea contents, SCS, and hyperkeratosis of individual udder quarters in Brown Swiss dairy cows. A second aim was to calculate within-udder mean and variance of milk contents and hyperkeratosis and to estimate genetic parameters for these new traits. An increase in within-udder variance for one milk content trait might be a sign for an infection in 1 quarter. In cases where novel traits, such as the quarter individual values discussed here, are included in a genomic breeding scheme, training sets will be composed of a mixture of all progeny-tested bulls and performance-tested cows available for the respective traits, and the accuracy of the conventional breeding values for the novel traits in the different cohorts is relevant. We thus report accuracies of EBV for the quarter individual milk contents and for the mean and variance of the milk contents.

\section{MATERIALS AND METHODS}

\section{Data}

A dataset of 1,064 cows phenotyped for fat, protein, lactose, and urea contents, as well as SCS was available; 1,403 cows were phenotyped for hyperkeratosis. These cows are a subset of the cows used in Kramer et al. (2013) and they belonged to 40 Swiss dairy herds with mean (SD) 32 (14) and range 13 to 70 cows per herd, and they were the daughters of 469 sires, with mean (SD) 4 (8) and range 1 to 67 daughters per sire. Phenotypes were collected between October 2009 and April 2011. Up to 3 measurements for the content traits per cow and from different lactations were available. For hyperkeratosis, up to 4 observations were available for each cow.

We aimed to take 1 milk sample of each udder quarter per cow close to dry-off for our study. The heritability of content traits is known to increase towards the end of lactation; thus, milk samples from the end of lactation should be best suited to reveal systematic differences between udder quarters. From another research project out of the same framework, a second quarter individual milk sample, taken approximately 1 wk earlier, was available from some cows. Therefore, up to 3 measurements of milk contents were available per cow from 2 lactations within a time period of 1.5 yr. Overall, 315 cows had repeated measurements in the dataset. The samples were used to analyze fat, protein, lactose, and urea contents, and SCS. Fat content, protein content, and lactose content (values on a percentage scale) were arcsin transformed (Sokal and Rohlf ,1995) to achieve a normal distribution for estimation of variance components and prediction of EBV; for lactose content, all arcsin values $<11.5(\mathrm{n}=540)$ were considered outliers and discarded. Urea content was measured in milli- grams per $100 \mathrm{~mL}$. Somatic cell score was derived from SCC, as described by Shook (1993) to achieve a normal distribution: $\mathrm{SCS}=\log _{2}(\mathrm{SCC} / 100,000)+3$.

Hyperkeratosis was subjectively scored by experienced persons from a research organization. In the framework of our study, each farm was visited 5 times and all animals present on the visiting day were evaluated for hyperkeratosis and other phenotypes. Therefore, not all lactations but the actual lactations during the collection period were incorporated in the scoring for hyperkeratosis of this study. Thickness and roughness of the teat-end callosity were taken into account, and teat ends were individually scored for each udder quarter with codes of 0 (no ring), 1 (smooth or slightly rough ring), 2 (rough ring), 3 (very rough ring), and 4 (open lesion or scabs), following Mein et al. (2001). Because only 27 udder quarters were scored with code 4 , codes 3 and 4 were combined for all analyses. After this editing, most teats were in class 3 and equal numbers of teats were in classes 1 and 2 .

For further analyses, we also used the mean and variance of milk content traits and scores for hyperkeratosis of the 4 udder quarters within 1 cow as desired traits. Mean and variance of the quarter specific milk content traits/hyperkeratosis scores were calculated for each cow and recording event. Mean and variance of milk content traits/hyperkeratosis score were treated as ordinary phenotypes with the variance reflecting the variability in the udder and the mean reflecting the specific milk content of the total composite milk. In total, 4,208 relevant animals (phenotyped cows and bulls with high effect on the population) were extracted from the Swiss Brown Swiss population database for which EBV were predicted, and the respective accuracies of EBV were calculated. Before estimation of variance components, all records with DIM $>3$ SD above mean and milk yield on test day $<3$ SD below mean were removed from the dataset. The 40 herds covered a wide range of extensively and intensively management but were representative of the Brown Swiss population in Switzerland. Thus, maximum DIM (after data editing) was 478 in extensively managed herds and maximum milk yield (after data editing) close to dry-off was 25.8 $\mathrm{kg}$ for single cows in intensively managed herds.

\section{Model}

Estimation of genetic parameters and prediction of EBV were done with ASReml 3.0 (Gilmour et al., 2009). Heritabilities, repeatabilities, and covariances between the udder quarters for fat content, protein content, lactose content, SCS, and hyperkeratosis were estimated from multivariate analyses, where each quarter was defined as a different trait. Because of problems 
with convergence for the trait urea content, additive genetic variance, variance of permanent environment, and residual variance for this trait were estimated by univariate analyses, and additive genetic and phenotypic correlation between udder quarters for urea content were obtained from bivariate analyses. Variance components for mean and variance of milk contents/ hyperkeratosis were also estimated from univariate models. For estimation of genetic parameters, the following overall linear animal model was used:

$$
\begin{aligned}
y_{i j k l m n o p} & =H Y S_{i j k o}+A F C_{l o}+\text { Lact }_{\text {mo }}+b_{1 o} \text { DIM }_{i j k l m n o p} \\
& +b_{2 o} \text { DIM }_{i j k l m n o p}^{2}+b_{3 o} \text { MkgTDay } \\
& +b_{4 j} \text { MkgLlmnop }_{\text {Lact }} \\
&
\end{aligned}
$$

where $y_{i j k l m n o p}=$ dependent variable (individual quarter fat, protein, urea, and lactose contents, individual quarter SCS, and hyperkeratosis) observed for animal $n$ in udder quarter $o$ and repeated observation $p ; H Y S_{i j k o}$ $=$ fixed effect of herd, year of calving, season of calving with $i=1$ to $40, j=1$ to $3, k=1$ to $4 ; A F C_{l o}=$ fixed effect of age at first calving in months $(\leq 28$, 29-30, 31-32, $\geq 33) ;$ Lact $_{m o}=$ fixed effect of lactation number $(1,2,3, \geq 4) ; D I M_{i j k l m n o p}=$ covariate DIM; $M k g T D a y_{i j k l m n o p}=$ covariate daily milk yield on the test day next to measurement; MkgLact $t_{i j k l m n o p}=$ covariate total milk yield in the lactation in which the measurement was done; $b_{10}$ to $b_{40}=$ linear regression coefficients for the covariates; $a_{n o}=$ random additive genetic effect of the oth udder quarter of the $n$th cow; $p_{n o}=$ random permanent environment effect of cow $e_{i j k l m n o p}=$ random residual effect of observation $p$.

For multivariate analysis of the quarter individual content traits, the distribution of random animal effect was defined as follows:

$$
\mathbf{a} \sim N(0, \mathbf{A} \otimes \mathbf{G})
$$

and

$$
\mathbf{G}=\left[\begin{array}{cccc}
\sigma_{a F L}^{2} & & & \\
\operatorname{cov}_{a_{F L F R}} & \sigma_{a F R}^{2} & & \\
\operatorname{cov}_{a_{F L R L}} & \operatorname{cov}_{a_{F R R L}} & \sigma_{a R L}^{2} & \\
\operatorname{cov}_{a_{F L R R}} & \operatorname{cov}_{a_{F R ~ R R}} & \operatorname{cov}_{a_{R L R R}} & \sigma_{a R R}^{2}
\end{array}\right],
$$

where $\sigma_{a_{F L}}^{2}, \sigma_{a_{F R}}^{2}, \sigma_{a_{R L}}^{2}$, and $\sigma_{a_{R R}}^{2}$ are the additive genetic variances of the udder quarters front left $(\mathbf{F L})$, front right (FR), rear left (RL), and rear right (RR), respectively; $\operatorname{cov}_{a_{X Y}}$ is the additive genetic covariance between the udder quarters with $X=\mathrm{FL}, \mathrm{FR}$, RL, or
$\mathrm{RR}$ and $Y=\mathrm{FL}, \mathrm{FR}, \mathrm{RL}$, or RR and $X \neq Y$; and $\mathbf{A}$ is the additive genetic relationship matrix.

For multivariate analysis of the quarter individual content traits the distribution of residual error was defined as follows:

$$
\mathbf{e} \sim N(0, \mathbf{I} \otimes \mathbf{H})
$$

and

$$
\mathbf{H}=\left[\begin{array}{cccc}
\sigma_{e_{F L}}^{2} & & & \\
\operatorname{cov}_{e_{F L F R}} & \sigma_{e_{F R}}^{2} & & \\
\operatorname{cov}_{e_{F L R L}} & \operatorname{cov}_{e_{F R R L}} & \sigma_{e_{R L}}^{2} & \\
\operatorname{cov}_{e_{F L R R}} & \operatorname{cov}_{e_{F R R R}} & \operatorname{cov}_{e_{R L R R}} & \sigma_{e_{R R}}^{2}
\end{array}\right],
$$

where $\sigma_{e_{F L}}^{2}, \sigma_{e_{F R}}^{2}, \sigma_{e_{R L}}^{2}$, and $\sigma_{e_{R R}}^{2}$ are the residual variance of the udder quarter FL, FR, RL, and RR, respectively; $\operatorname{cov}_{e_{X Y}}$ is the residual covariance between the udder quarters with $X=\mathrm{FL}, \mathrm{FR}, \mathrm{RL}$, or RR and $Y=\mathrm{FL}$, $\mathrm{FR}, \mathrm{RL}$, or RR and $X \neq Y$; and $\mathbf{I}$ is an identity matrix.

For multivariate analysis of the quarter individual content traits, the distribution of permanent environment effect (the same permanent environment for each udder quarter) was defined as follows:

$$
\mathbf{p} \sim N\left(0, \mathbf{I} \sigma_{p}^{2}\right),
$$

where $\sigma_{p}^{2}$ is the variance of permanent environment and $\mathbf{I}$ is an identity matrix.

For bivariate analyses, in order to estimate covariances between the udder quarters for urea content, the multivariate model was used but matrices $\mathbf{G}$ and $\mathbf{H}$ were restricted to 2 respective udder quarters.

For univariate analysis of urea content and of mean and variance of the milk content traits and hyperkeratosis, the linear model as described above was used but the additive genetic effect was simplified to an additive genetic effect of animal instead of additive genetic effect of udder quarter and cow. Thus, the distributions of random effects for univariate analyses were simplified to the following:

$$
\begin{aligned}
& \mathbf{a} \sim N\left(0, \mathbf{A} \sigma_{a}^{2}\right), \\
& \mathbf{e} \sim N\left(0, \mathbf{I} \sigma_{e}^{2}\right), \\
& \mathbf{p} \sim N\left(0, \mathbf{I} \sigma_{p}^{2}\right),
\end{aligned}
$$

where $\sigma_{a}^{2}$ is the additive genetic variance, $\sigma_{e}^{2}$ is the residual variance, $\sigma_{p}^{2}$ is the variance of permanent envi- 
Table 1. Minimum, maximum, and mean values and standard deviation (SD) of independent variables used for estimation of variance components

\begin{tabular}{lrlrrrr}
\hline Trait & $\mathrm{n}$ & Scale & Minimum & Maximum & Mean & SD \\
\hline Herd-year-season of calving & 480 & & & & & \\
Age at first calving & 4 & Class & 1 & 4 & 2.52 & 1.17 \\
Lactation number & 4 & Class & 1 & 4 & 2.65 & 1.21 \\
DIM & & Day & 205 & 478 & 316 & 47.89 \\
Milk yield on test-day & & Kilograms & 4 & 25.8 & 14.56 & 3.58 \\
Milk yield in lactation & & Kilograms & 2,290 & 12,180 & 6,646 & 1,218 \\
\hline
\end{tabular}

ronment, $\mathbf{I}$ is an identity matrix, and $\mathbf{A}$ is the additive genetic relationship matrix.

Summary statistics of the independent variables (after data editing) are given in Table 1. Starting from the complete models above, PROC MIXED in SAS 9.2 (SAS Institute, 2008) was used to identify all fixed factors that significantly $(P<0.05)$ influenced the trait studied by stepwise analysis. Only significant effects were included in the model used for estimation of genetic parameters (Table 2), which is a widely used strategy in multiple trait analyses (see Nielsen et al., 2005; König et al., 2006). For hyperkeratosis, we used lactation milk yield (MkgLact) instead of MkgTDay, because we assumed that lesions at teat ends are not primarily influenced by the amount of milk from one specific test day but more by the average performance of the complete lactation.

To test for differences in hyperkeratosis, fat content, protein content, lactose content, urea content, and SCS between the four udder quarters, a paired $t$-test with PROC MIXED (SAS Institute, 2008) was used with the models shown in Table 2 for the specific trait. The only modification of the models in Table 2 was that random additive genetic and permanent environment effects were replaced by a fixed effect for udder quarter. Thus, it was possible to detect differences of milk contents and hyperkeratosis between udder quarters.

Heritabilities $\left(h^{2}\right)$ and repeatabilities $\left(w^{2}\right)$ were derived from the variance components as follows:

$$
h^{2}=\frac{\sigma_{a}^{2}}{\sigma_{a}^{2}+\sigma_{p}^{2}+\sigma_{e}^{2}}
$$

and

$$
w^{2}=\frac{\sigma_{a}^{2}+\sigma_{p}^{2}}{\sigma_{a}^{2}+\sigma_{p}^{2}+\sigma_{e}^{2}},
$$

where $\sigma_{a}^{2}$ is the additive genetic variance, $\sigma_{p}^{2}$ is the variance of permanent environment, and $\sigma_{e}^{2}$ is the residual variance.

Accuracy $\left(\boldsymbol{r}_{T I}\right)$ of EBV was calculated as

$$
r_{T I}=\sqrt{1-\frac{S E^{2}}{(1+f) \sigma_{a}^{2}}},
$$

where $S E^{2}$ is the squared standard error of the EBV, $f$ represents the inbreeding coefficient (derived from the diagonal element of the additive genetic numerator relationship matrix), and $\sigma_{a}^{2}$ is the additive genetic variance of the specific trait estimated from the data. The formula above was based on Misztal and Wiggans (1988), and $\sigma_{a}^{2}$ was multiplied by $(1+f)$ as suggested by Jamrozik et al. (2000) to account for inbreeding.

\section{RESULTS AND DISCUSSION}

\section{Phenotypic Differences Between the Udder Quarters}

In Table 3, mean values for individual udder quarter milk content traits are shown. Fat content of the 2 front quarters was significantly higher than fat content of the 2 rear quarters $(P<0.05)$. The same tendency was observed for protein content, although the differ-

Table 2. Effects selected for evaluated traits: herd, year, season of calving $(H Y S)$, age at first calving $(A F C)$, days in milk at day of sampling $(D I M)$, milk yield on the nearest test day (MkgTDay) and of the respective lactation $(M k g L a c t)$, additive genetic effect $(a)$, permanent environment effect $(p)$, and residual effect $(e)^{1}$

\begin{tabular}{lcccccccccc}
\hline Trait & $H Y S$ & AFC & Lact & DIM & DIM & MkgTDay & MkgLact & $a$ & $p$ & $e$ \\
\hline Fat content & $\mathrm{X}$ & $\mathrm{X}$ & $\mathrm{X}$ & $\mathrm{X}$ & $\mathrm{X}$ & & & $\mathrm{X}$ & $\mathrm{X}$ & $\mathrm{X}$ \\
Protein content & $\mathrm{X}$ & & $\mathrm{X}$ & $\mathrm{X}$ & & $\mathrm{X}$ & & $\mathrm{X}$ & $\mathrm{X}$ & $\mathrm{X}$ \\
Lactose content & $\mathrm{X}$ & $\mathrm{X}$ & $\mathrm{X}$ & & & $\mathrm{X}$ & & $\mathrm{X}$ & $\mathrm{X}$ & $\mathrm{X}$ \\
Urea content & $\mathrm{X}$ & $\mathrm{X}$ & $\mathrm{X}$ & $\mathrm{X}$ & $\mathrm{X}$ & & & $\mathrm{X}$ & $\mathrm{X}$ & $\mathrm{X}$ \\
SCS & $\mathrm{X}$ & & $\mathrm{X}$ & & & $\mathrm{X}$ & & $\mathrm{X}$ & $\mathrm{X}$ & $\mathrm{X}$ \\
Hyperkeratosis & $\mathrm{X}$ & & $\mathrm{X}$ & $\mathrm{X}$ & $\mathrm{X}$ & & $\mathrm{X}$ & $\mathrm{X}$ & $\mathrm{X}$ & $\mathrm{X}$ \\
\hline
\end{tabular}

${ }^{1} \mathrm{X}$ indicates that the effect was significant $(P<0.05)$ and included in the model for a given trait. 
ence between rear left quarter and the 2 front quarters was not statistically significant. For lactose content, this relation was the other way round, lactose content of rear udder quarters being significantly higher than of front udder quarters $(P<0.05)$. Concentration of urea did not differ between the 4 udder quarters and no clear tendency was observed for SCS. These results are in line with those reported by Berglund et al. (2007). These authors also found significantly higher fat content in milk of the front quarters $(P<0.05)$ and significantly higher lactose content in milk of the rear quarters $(P<0.05)$. In contrast to our work, Berglund et al. (2007) did not observe the difference between the front and rear quarters in protein content.

The pattern observed for the fat, protein, and lactose contents is presumably due to the role of lactose in osmotic regulation. As explained by von Engelhardt and Breves (2004), lactose is the main osmotic factor of milk. The higher concentration of lactose in the rear quarters causes more water to diffuse into the milk of these quarters. This is supported by Forsbäck et al. (2010), who found that rear quarters produce more milk than front quarters. The increased secretion of water causes an increased dilution of the synthesized and secreted quantities of fat and protein in the rear quarters.

For hyperkeratosis, we found no systematic differences between front and rear udder quarters. This is in contrast to the findings of Seykora and McDaniel (1985), who found that front teats tend to have slightly higher lesion scores than rear teats. These authors also found that cows with high scores for hyperkeratosis have significantly higher SCC $(P<0.05)$. Neijenhuis et al. (2001) assumed that the rough surface of teats with high scores for hyperkeratosis provides a good environment for pathogenic bacteria and prevents successful disinfection of teats. High hyperkeratosis scores are a result of thick callosity. The thick callosity expands the teat canal and so bacteria can get into the mammalian gland more easily. In contrast to Seykora and McDaniel (1985), Chrystal et al. (1999) found no significant influence of hyperkeratosis on SCS. Breen et al. (2009) found that cows with mild and moderate hyperkeratosis have a lower risk of having an SCC $\geq 200,000$ cells $/ \mathrm{mL}$ than cows with high or low hyperkeratosis. Therefore, based on the literature, we cannot determine whether a low or a moderate lesion score is positive or whether the lesion score has any influence on SCS at all.

\section{Genetic Parameters for Mean Milk Contents}

Variance components, heritability, and repeatability for mean and variance of fat, protein, lactose, and urea contents, SCS, and hyperkeratosis are presented in Table 4. Compared with the literature, our heritability estimates for mean fat content of $0.10 \pm 0.06$, mean protein content of $0.21 \pm 0.10$, and mean lactose content of $0.08 \pm 0.07$ were low. This was also reflected in low $r_{T I}$ values (close to 0.30 ) for the milk content traits. It has to be considered that our estimates were based on just 1 or 2 milk samples that were taken at the end of lactation. In contrast, other studies (e.g., Yin et al., 2012) or routine breeding value estimations are based on random regression test-day models with approximately 10 milk samples from all DIM between 5 and 365. The relatively low repeatabilities for mean milk content traits in our study (Table 4) of values around 0.4 also reflect the high gain of information that additional measurements from different DIM would provide. Our heritability for mean urea content of 0.19 \pm 0.08 was in line with estimates from Yin et al. (2012), who estimated a heritability of close to 0.13 during the complete lactation and with results from Stamer et al. (2011), who estimated heritabilities between 0.10 and 0.22 for urea content in first and second lactation. As shown by Yin et al. (2012), milk urea content is a trait with small variation across the lactation compared with the other milk contents. Therefore, additional measurements of urea content would provide little additional information, and 1 measurement appears sufficient to estimate a realistic heritability for urea content in milk.

Heringstad et al. (2006) estimated a heritability for SCS of 0.08 for 1 milk sample of first-lactating cows, Rupp and Boichard (1999) found a heritability of 0.17

Table 3. Mean values (solutions of a mixed model) for milk composition traits and hyperkeratosis for the udder quarters front left (FL), front right (FR), rear left (RL), and rear right (RR) within each of the 6 traits

\begin{tabular}{lclccccc}
\hline Trait & $\mathrm{n}$ & Scale & Mean FL & Mean FR & Mean RL & Mean RR & SD \\
\hline Fat content & 5,275 & Percentage & $3.73^{\mathrm{a}}$ & $3.73^{\mathrm{a}}$ & $3.49^{\mathrm{b}}$ & $3.51^{\mathrm{b}}$ & 0.04 \\
Protein content & 5,244 & Percentage & $4.04^{\mathrm{a}}$ & $4.05^{\mathrm{a}}$ & $4.01^{\mathrm{ab}}$ & $3.99^{\mathrm{b}}$ & 0.02 \\
Lactose content & 5,259 & Percentage & $4.56^{\mathrm{a}}$ & $4.48^{\mathrm{b}}$ & $4.61^{\mathrm{c}}$ & $4.60^{\mathrm{c}}$ & 0.02 \\
Urea content & 5,232 & $\mathrm{mg} / 100 \mathrm{~mL}$ & $21.94^{\mathrm{a}}$ & $21.71^{\mathrm{a}}$ & $22.06^{\mathrm{a}}$ & $21.88^{\mathrm{a}}$ & 0.20 \\
SCS & 5,338 & & $3.14^{\mathrm{a}}$ & $3.30^{\mathrm{b}}$ & $3.12^{\mathrm{a}}$ & $3.09^{\mathrm{a}}$ & 0.05 \\
Hyperkeratosis & 8,645 & Code 0 - 3 & $0.93^{\mathrm{ab}}$ & $0.96^{\mathrm{b}}$ & $0.94^{\mathrm{b}}$ & $0.91^{\mathrm{a}}$ & 0.02 \\
\hline a-c Different superscript letters indicate significant differences within 1 trait between the 4 udder quarters $(P$ \\
$<$ 0.05).
\end{tabular}


for SCS, and Koeck et al. (2010) estimated a heritability of 0.13 for SCS (based on the arithmetic mean of all milk samples from different lactations). Our heritability estimate of $0.16 \pm 0.08$ is in line with these results. Yin et al. (2012) showed that the heritability of SCS varies in a wide range over the lactation, with peak values near 0.50 . Using an average of all milk samples of 1 lactation in a univariate analysis (Rupp and Boichard, 1999; Koeck et al., 2010) yields slightly higher heritabilities than the use of 1 or 2 milk samples in a univariate analysis (Heringstad et al., 2006 and the cur- rent study). For mean hyperkeratosis, we estimated a heritability of $0.22 \pm 0.06$, which is in line with Seykora and McDaniel (1985), who estimated a heritability of 0.24 for this trait.

\section{Genetic Parameters for Variance of Milk Contents}

The variance of milk content traits/hyperkeratosis score between the udder quarters of a cow was generally a trait with a low heritability $(<0.10)$. Variances of fat $(0.06 \pm 0.06)$, protein $(0.01 \pm 0.05)$, and urea $(0.04$

Table 4. Additive genetic variance $\left(\sigma_{a}^{2}\right)$, permanent environment variance $\left(\sigma_{p e}^{2}\right)$, residual variance $\left(\sigma_{e}^{2}\right)$, heritability $\left(h^{2}\right)$, and repeatability $\left(w^{2}\right)$, with their standard error (SE), mean accuracy of EBV for all 4,208 animals in the dataset $\left(r_{T I}\right.$ All), for phenotyped cows $\left(r_{T I}\right.$ Cows), and for 30 bulls with at least 10 phenotyped daughters in the dataset $\left(r_{T I}\right.$ Bulls) for individual udder quarter traits as well as genetic parameters and accuracies for mean and variance of within-udder milk content traits ${ }^{1}$

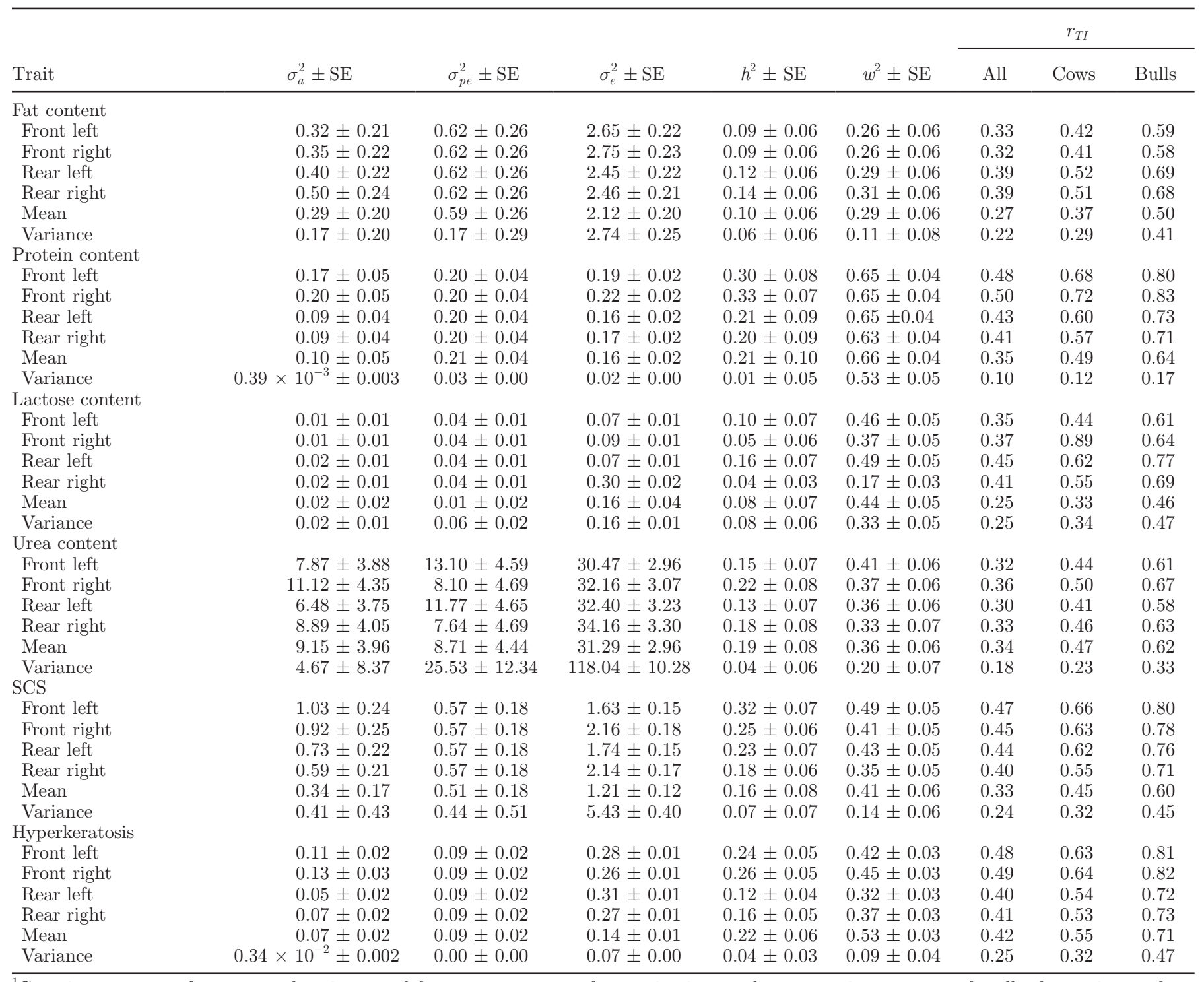

${ }^{1}$ Genetic parameters for mean and variance and for urea content are from univariate analyses; genetic parameters for all other traits are from multivariate analyses. Permanent environment variance 
\pm 0.06 ) contents showed no significant heritability (SE higher than the point estimate). In addition, the variances of lactose content $(0.08 \pm 0.06)$ and hyperkeratosis $(0.04 \pm 0.03)$ had a heritability that barely differed from zero. In contrast to the marginal heritabilities for the variance traits, some of these traits showed high repeatabilities. For example, the essentially not heritable trait variance of protein content had a repeatability of $0.53 \pm 0.05$ and variance of lactose content with a heritability of 0.08 had a repeatability of $0.33 \pm 0.05$ (Table 4).

From our results, we conclude that the variance of milk content does not appear to be a very useful indicator to reflect the physiological stability of milk production or composition that could be used for genetic improvement. However, the substantial repeatabilities of some of the variability traits suggest that nongenetic events (not only in the present lactation, but also perhaps during rearing or in former lactations) may cause a sustained imbalance between milk composition in udder quarters, which may affect the long-term performance of a cow or the composition of milk of different quarters.

Forsbäck et al. (2010) suggested that a bacterial infection in one quarter leads to higher protein content and lower lactose content in milk of the infected quarter, even in the case of subclinical mastitis. As proposed by Forsbäck et al. (2010), the between-quarter phenotypic variance of lactose and protein may thus be used as a management tool for early detection of mastitis.

\section{Genetic Parameters on the Udder Quarter Level}

The results of the multivariate analysis of udder quarter milk content traits are shown in Table 4. Except for hyperkeratosis, the heritabilities from multivariate analysis were on average higher than the heritabilities from univariate analysis of the mean content trait.

A multivariate analysis for milk contents of different udder quarters also had advantages for the accuracy of EBV. A multivariate analysis of milk composition traits (Table 4) led to $r_{T I}$ of EBV for each udder quarter that were on average higher than the $r_{T I}$ of EBV estimated for the mean content traits (Table 4). The advantage of multivariate analysis for $r_{T I}$ seems to be higher than the advantage on heritability and was also observed for hyperkeratosis. It was only the $r_{T I}$ of EBV for urea content that did not benefit, because $r_{T I}$ was derived from univariate analyses and the multivariate analyses of individual udder quarter urea content did not converge.

As for the analysis of milk content on the phenotypic scale, some orderliness could also be observed for variance components. Protein content, SCS, and hyperkeratosis showed higher heritabilities on the front quarters, whereas fat content had a higher heritability for the rear udder quarters. No clear difference could be observed for lactose and urea contents. For fat content, SCS, and hyperkeratosis, the higher heritability for the front or rear quarters was due to both higher additive genetic variance and lower residual variance. In general, the influence of higher additive genetic variance is more distinct than the influence of lower residual variance. For protein content, the heritability for the front quarters was higher, even though the residual variance of the front quarters was higher as well.

In Figures 1 to 3, phenotypic, additive genetic, and residual correlations between the udder quarters for the different traits are shown. The additive genetic correlation and the phenotypic correlation of urea content (Figure 2) for the 4 udder quarters was close to 1 , with small SD in all cases $(0.93 \pm 0.18$ to $0.99 \pm 0.11$ for the additive genetic correlation, $0.90 \pm 0.08$ to 0.94 \pm 0.06 for the phenotypic correlation). The residual correlations between udder quarters for urea content were slightly lower $(0.86 \pm 0.12$ to $0.91 \pm 0.10)$. In contrast, the additive genetic and phenotypic correlations of fat, protein, and lactose contents (Figures 1 and 2) were on average weaker and had higher SD (i.e., 0.62 \pm 0.47 to $0.99 \pm 0.19$ for additive genetic correlation of fat content). Remarkably, the correlations between the 2 front and the 2 rear quarters were always higher than the correlation between a front and a rear quarter, respectively. Accordingly for fat content, we found additive genetic correlations between the 2 rear quarters of $0.99 \pm 0.19$ and $0.76 \pm 0.42$ between the 2 front quarters but additive genetic correlations of just $0.62 \pm$ 0.47 between the left quarters and $0.64 \pm 0.44$ between the right quarters. The lowest additive genetic $(0.11 \pm$ 0.50 to $0.57 \pm 0.34)$ and phenotypic correlations $(0.43$ \pm 0.16 to $0.55 \pm 0.15)$ were found for SCS between quarters (Figure 3).

These findings might reflect the different ways that milk contents are synthesized. Milk fat is synthesized by different enzymes on the rough endoplasmic reticulum (Baumann et al., 2006), proteins are produced enzymatically on the surface of the ribosomes and are enzymatically modified in the Golgi apparatus (Schmidt, 1971). Lactose is also enzymatically synthesized from glucose (von Engelhardt and Breves, 2004). In contrast to these milk contents, urea is not synthesized in the secretory cells of the udder, but in the liver in order to metabolize the toxic ammonia. From there, it is transported via the blood into the udder and then secreted into the milk. Milk is just a second pathway for excreting urea besides urine (von Engelhardt and Breves, 2004). This is supported by findings of Nielsen et al. (2005), who compared milk contents between healthy 
Phenotypic correlations fat content

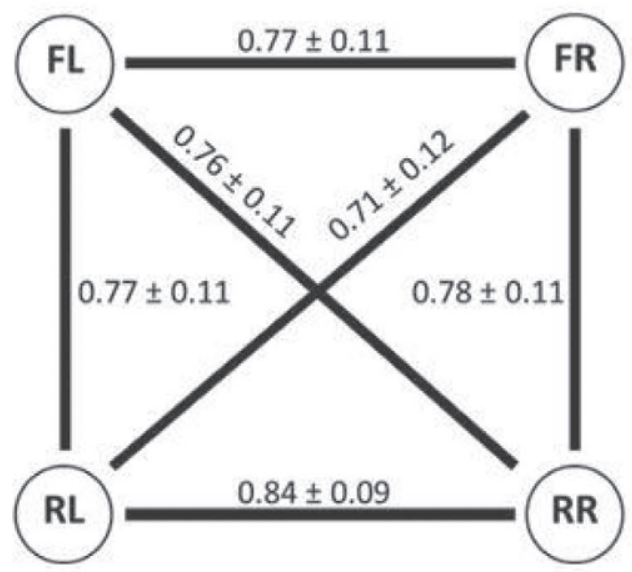

Additive genetic correlations fat content

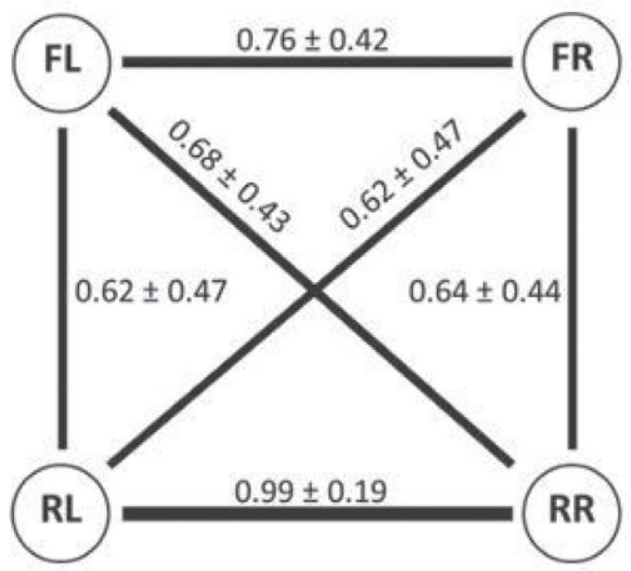

Residual correlations fat content

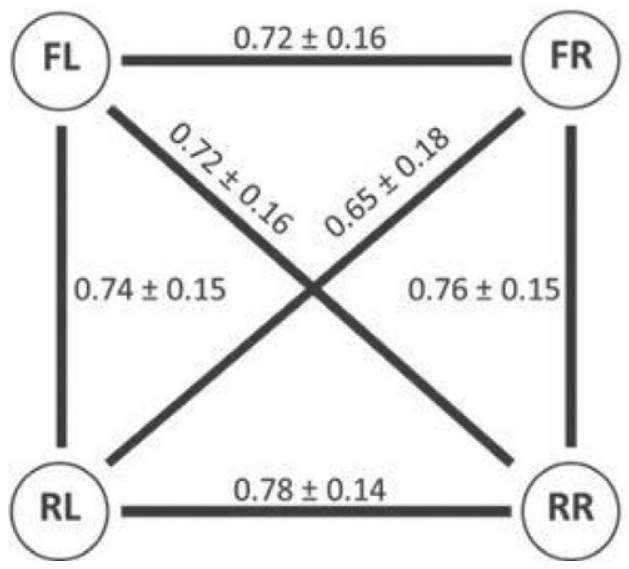

Phenotypic correlations protein content

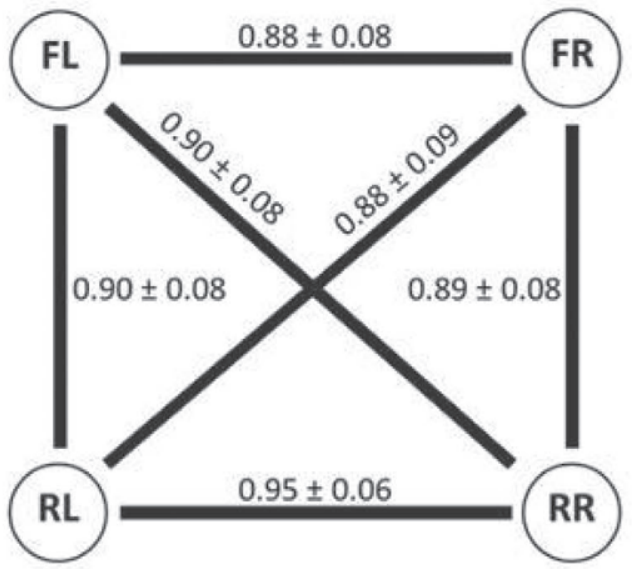

Additive genetic correlations protein content

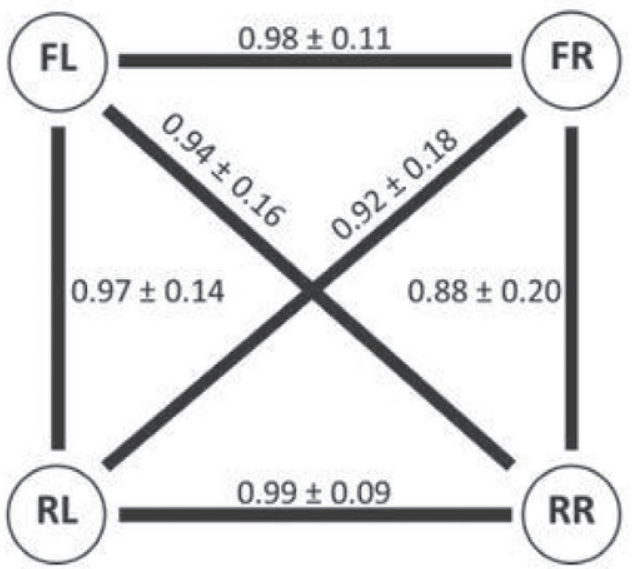

Residual correlations protein content

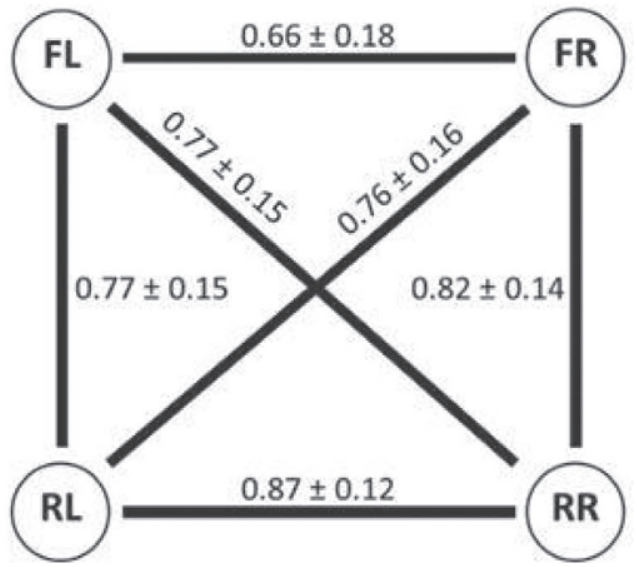

Figure 1. Phenotypic, additive genetic, and residual correlations between front left (FL), front right (FR), rear left (RL), and rear right (RR) udder quarter for fat and protein contents. Line thickness is proportional to the correlations between the udder quarters. 
Phenotypic correlations lactose content

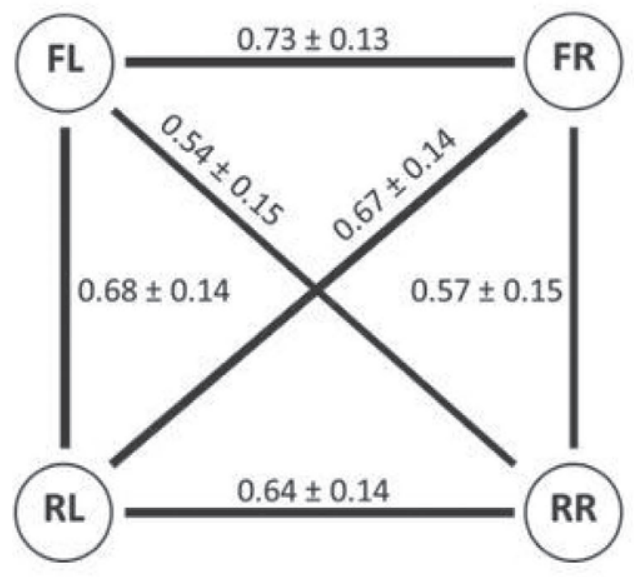

Additive genetic correlations lactose content

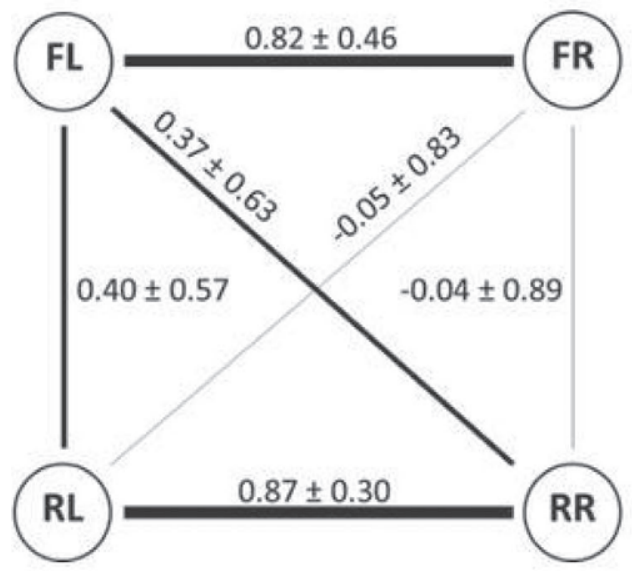

Residual correlations lactose content

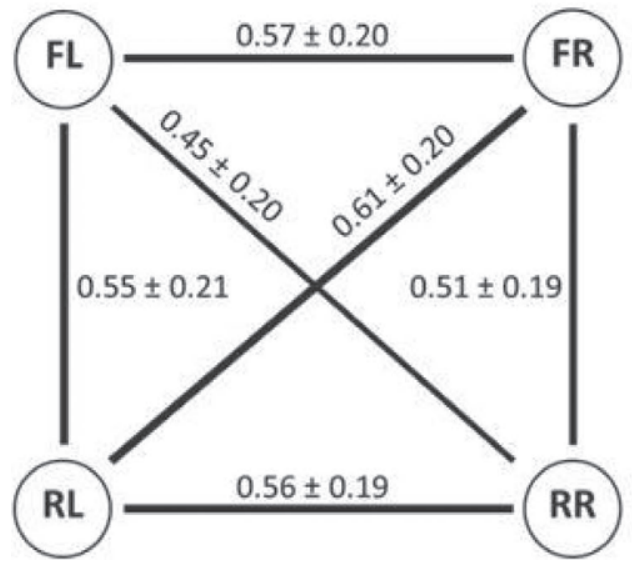

Phenotypic correlations urea content

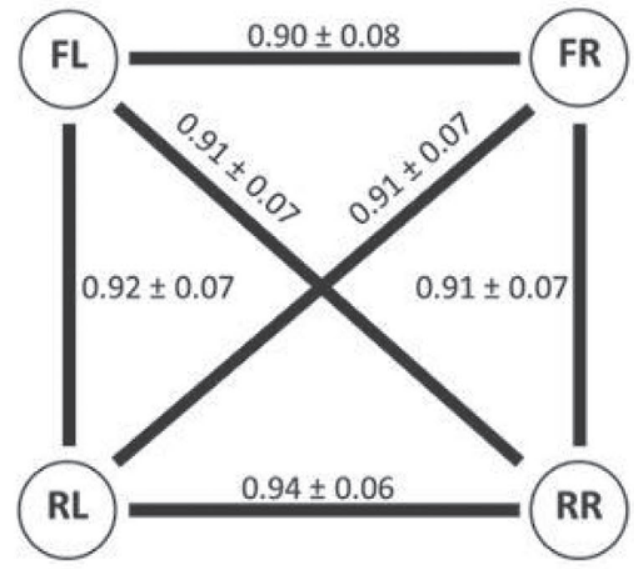

Additive genetic correlations urea content

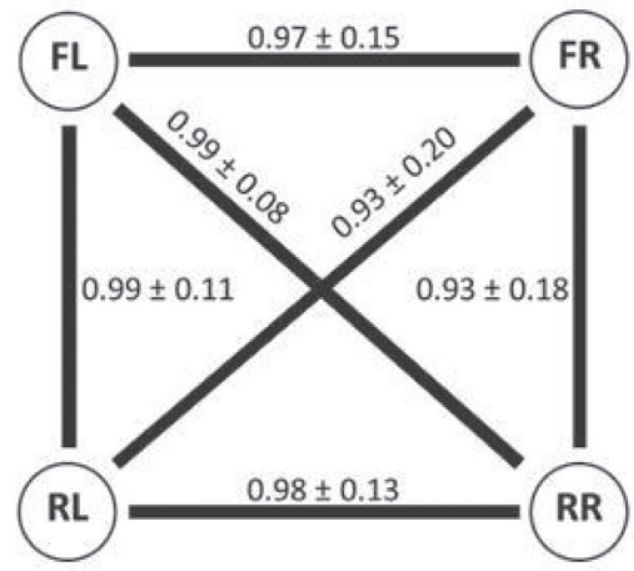

Residual correlations urea content

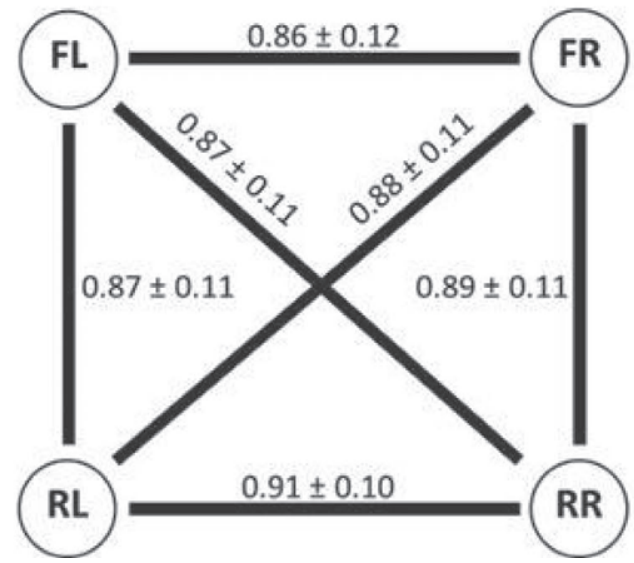

Figure 2. Phenotypic, additive genetic, and residual correlations between front left (FL), front right (FR), rear left (RL), and rear right (RR) udder quarter for lactose and urea contents. Line thickness is proportional to the correlations between the udder quarters. 
Phenotypic correlations SCS

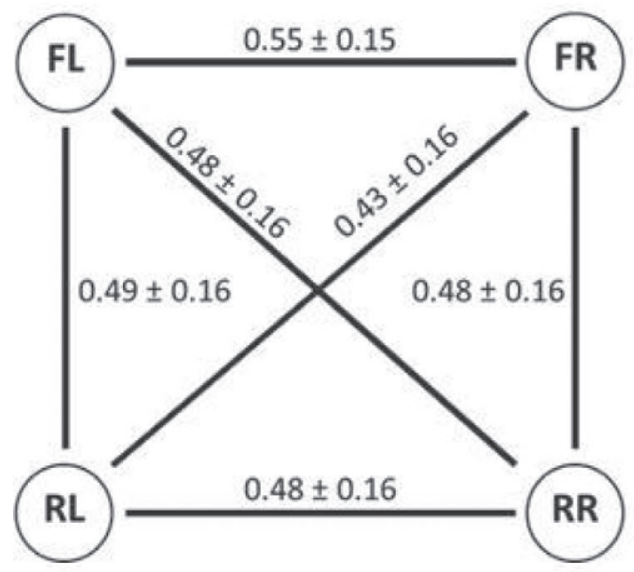

Additive genetic correlations SCS

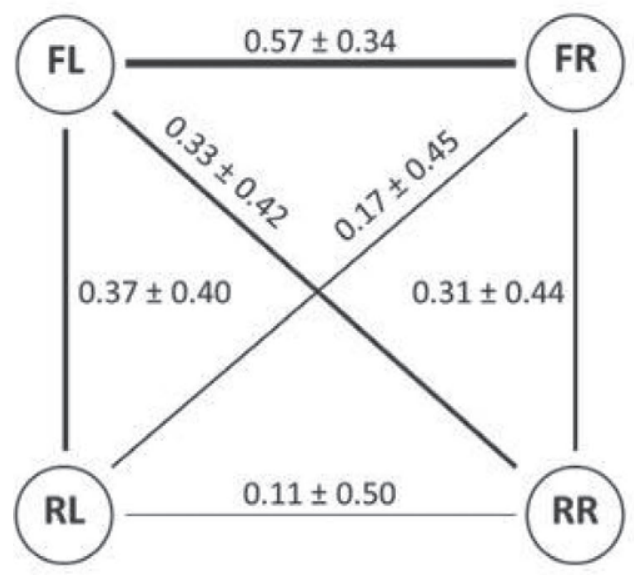

Residual correlations SCS

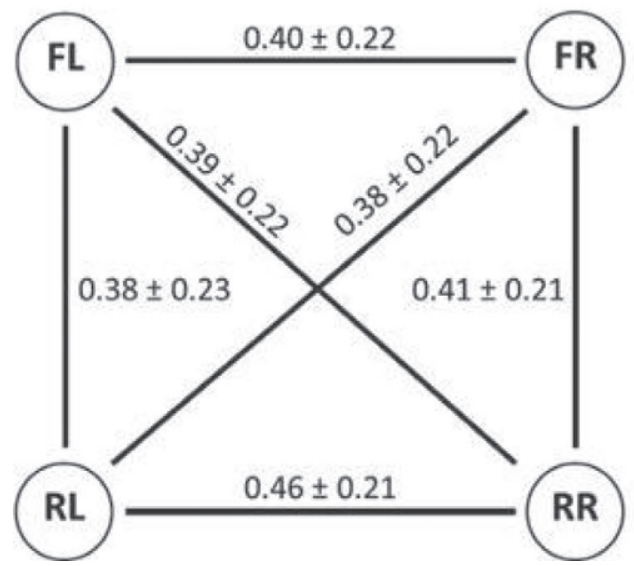

Phenotypic correlations hyperkeratosis

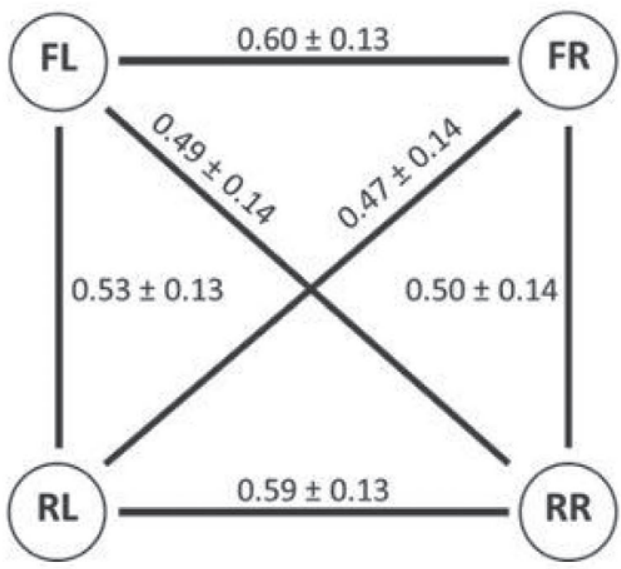

Additive genetic correlations hyperkeratosis

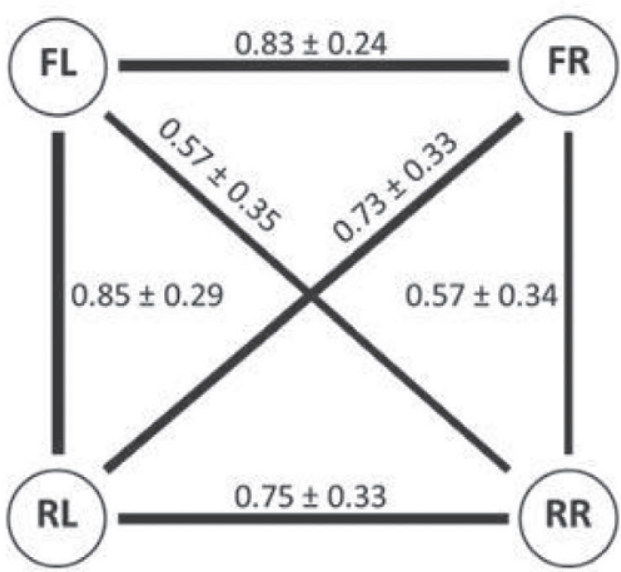

Residual correlations hyperkeratosis

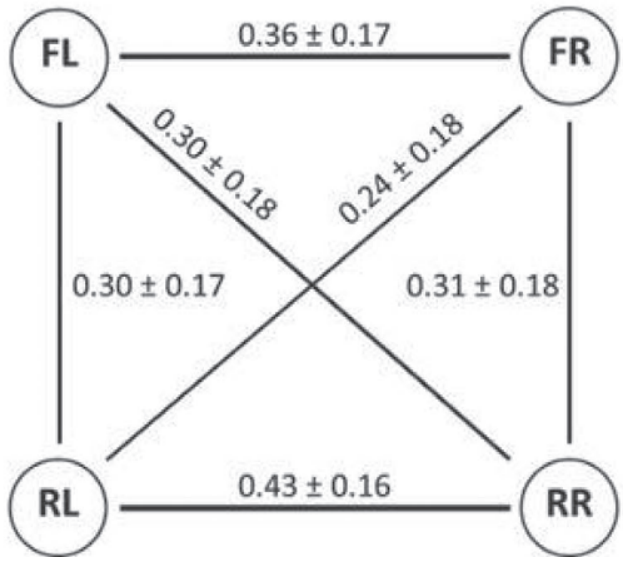

Figure 3. Phenotypic, additive genetic, and residual correlations between front left (FL), front right (FR), rear left (RL), and rear right (RR) udder quarter for SCS and hyperkeratosis. Line thickness is proportional to the correlations between the udder quarters. 
udder quarters and udder quarters with mastitis. The authors found that urea content did not differ between healthy and affected quarters, whereas affected quarters showed significantly higher protein contents and significantly lower lactose contents. Thus, fat, protein, and lactose are produced in each quarter individually, whereas urea is not. Different heritabilities between front and rear quarters and the reduced additive genetic correlations between front and rear quarters in contrast to correlations between front quarters or between rear quarters, respectively, suggest that fat content, protein content, and lactose content of front and rear quarters can be considered different traits. Because of the high SE of correlations between front and rear quarters, this suggestion is very obvious for lactose content (Figure $2)$.

If records for single quarters were available from routine testing or with increased use of automatic milking systems, the prime benefit would certainly be in the use of this information for the purpose of monitoring and managing animal health (e.g., detecting single quarters that deviate in production or milk composition from the other quarters, which may be an early indicator of mastitis). However, aiming at a more balanced milk production or composition across quarters or giving greater weight to more informative udder quarters in an index may make sense from a breeding point of view. Larger studies than the current pilot study are needed to assess whether this is a path worth pursuing.

\section{CONCLUSIONS}

We showed that recording traits for udder quarters separately allows a more differentiated assessment of milk composition and udder health, which can be used for management and breeding purposes and as indicators of udder health. We observed significant systematic differences in contents of fat, protein, and lactose between front and rear udder quarters, whereas content of urea, SCS, and hyperkeratosis did not differ systematically between front and rear quarters. We also found systematic differences in heritabilities for fat content, protein content, and hyperkeratosis but not for urea content and lactose content. These differences reflect the different tissues where the milk constituents are synthesized. The variance of milk content traits is of limited informational value as an auxiliary trait to breed for udder health, but may be a helpful indicator trait to detect early or subclinical mastitis.

\section{ACKNOWLEDGMENTS}

The authors gratefully acknowledge co-funding from the European Commission, under the Seventh Frame- work Program for Research and Technological Development, for the Collaborative Project LowInputBreeds (grant agreement no. 222623). However, the views expressed by the authors do not necessarily reflect the views of the European Commission, nor do they in any way anticipate the Commission's future policy in this area.

\section{REFERENCES}

Bauman, D. E., I. H. Mather, R. J. Wall, and A. L. Lock. 2006. Major advances associated with the biosynthesis of milk. J. Dairy Sci. 89:1235-1243.

Berglund, I., G. Pettersson, K. Östensson, and K. SvennerstenSjaunja. 2007. Quarter milking for improved detection of increased SCC. Reprod. Domest. Anim. 42:427-432.

Breen, J. E., A. J. Bradley, and M. J. Green. 2009. Quarter and cow risk factors associated with a somatic cell count greater than 199,000 cells per milliliter in United Kingdom dairy cows. J. Dairy Sci. $92: 3106-3115$.

Chrystal, M. A., A. J. Seykora, and L. B. Hansen. 1999. Heritabilities of teat end shape and teat diameter and their relationships with somatic cell score. J. Dairy Sci. 82:2017-2022.

Forsbäck, L., H. Lindmark-Månsson, A. Andrén, M. Åkerstedt, L. Andrée, and K. Svennersten-Sjaunja. 2010. Day-to-day variation in milk yield and milk composition at the udder-quarter level. J. Dairy Sci. 93:3569-3577.

Gilmour, A. R., B. J. Gogel, B. R. Cullis, and R. Thompson. 2009. ASReml User Guide. Release 3.0. VSN International Ltd., Hemel Hempstead, UK.

Heringstad, B., D. Gianola, Y. M. Chang, J. Ødegård, and G. Klemetsdal. 2006. Genetic associations between clinical mastitis and somatic cell score in early first-lactation cows. J. Dairy Sci. 89:2236-2244.

Jamrozik, J., L. R. Schaeffer, and G. B. Jansen. 2000. Approximate accuracies of prediction from random regression models. Livest. Prod. Sci. 66:85-92.

Koeck, A., B. Heringstad, C. Egger-Danner, C. Fuerst, P. Winter, and B. Fuerst-Waltl. 2010. Genetic analysis of clinical mastitis and somatic cell count traits in Austrian Fleckvieh cows. J. Dairy Sci. 93:5987-5995.

König, S., F. Köhn, K. Kuwan, H. Simianer, and M. Gauly. 2006. Use of repeated measures analysis for evaluation of genetic background of dairy cattle behavior in automatic milking systems. J. Dairy Sci. 89:3636-3644.

Kramer, M., M. Erbe, B. Bapst, A. Bieber, and H. Simianer. 2013. Estimation of genetic parameters for novel functional traits in Brown Swiss cattle. J. Dairy Sci. http://dx.doi.org/10.3168/jds.20126236.

Mein, G. A., F. Neijenhuis, W. F. Morgan, D. J. Reinemann, J. E. Hillerton, J. R. Baines, I. Ohnstad, M. D. Rasmussen, L. Timms, J. S. Britt, R. Farnsworth, N. Cook, and T. Hemling. 2001. Evaluation of bovine teat condition in commercial dairy herds: 1 . Noninfectious factors. Proc. 2nd Int. Symp. Mastitis and Milk Quality, Vancouver, BC, Canada. National Mastitis Council, Madison, WI; American Association of Bovine Practitioners, Rome, GA.

Misztal, I., and G. R. Wiggans. 1988. Approximation of prediction error variance in large-scale animal models. J. Dairy Sci. 71(Suppl. 2):27-32.

Neijenhuis, F., G. A. Mein, J. S. Britt, D. J. Reinemann, J. E. Hillerton, R. Farnsworth, J. R. Baines, T. Hemling, I. Ohnstad, N. B. Cook, and W. F. Morgan. 2001. Relationship between teat-end callosity or hyperkeratosis and mastitis. Proc. 2nd Int. Symp. Mastitis and Milk Quality, Vancouver, BC, Canada. National Mastitis Council, Madison, WI; American Association of Bovine Practitioners, Rome, GA.

Nielsen, N. I., T. Larsen, M. Bjerring, and K. L. Ingvartsen. 2005. Quarter health milking interval and sampling time during milk- 
ing affect the concentration of milk constituents. J. Dairy Sci. 88:3186-3200.

Rupp, R., and D. Boichard. 1999. Genetic parameters for clinical mastitis, somatic cell score, production, udder type traits, and milking ease in first lactation Holsteins. J. Dairy Sci. 82:2198-2204.

SAS Institute. 2008. Base SAS 9.2 Procedures Guide. SAS Institute Inc., Cary, NC.

Schmidt, G. H. 1971. Biology of Lactation. H. W. Freeman and Co., San Francisco, CA.

Seykora, A. J., and B. T. McDaniel. 1985. Heritability of teat traits and their relationships with milk yield, somatic cell count, and percent two-minute milking. J. Dairy Sci. 68:2670-2683.

Shook, G. E. 1993. Genetic improvement of mastitis through selection on somatic cell count. Vet. Clin. North Am. Food Anim. Pract. 9:563-581.
Sokal, R. R., and F. J. Rohlf. 1995. Biometry: The Principles and Practice of Statistics in Biological Research. H. W. Freeman, New York, NY.

Stamer, E., W. Brade, and G. Thaller. 2011. Modellentwicklung und Schätzung genetischer Parameter für den Harnstoffgehalt in der Milch erst- und zweitlaktierender Holstein-Kühe. Zuchtungskunde 83:104-117.

von Engelhardt, W., and G. Breves. 2004. Physiologie der Haustiere. Enke Verlag, Stuttgart, Germany.

Yin, T., B. Bapst, U. U. v. Borstel, H. Simianer, and S. König. 2012. Genetic parameters for Gaussian and categorical traits in organic and low input dairy cattle herds based on random regression methodology. Livest. Sci. 147:159-169. 